\title{
INTOLERÂNCIA, RACISMO E GENOCÍDIO RELIGIOSO DO POVO NEGRO: PENSANDO SOBRE AS CATEGORIAS AFRO-RELIGIOSAS DA "POLÍTICA DOS TERREIROS"1
}

\section{Mariana Ramos de Morais ${ }^{2}$}

Resumo: Neste texto, apresento comentários ao artigo "A 'política dos terreiros' contra o racismo religioso e as políticas 'cristofascistas", de Ana Paula Mendes de Miranda, destacando três categorias mobilizadas pelos afro-religiosos na sua luta pela garantia de seus direitos frente ao acirramento dos ataques de grupos evangélicos às religióes afro-brasileiras, quais sejam: "intolerância religiosa", "racismo religioso" e "genocídio religioso do povo negro". A proposta é pensar sobre como essas categorias têm sido constituídas na "política dos terreiros", expressão adotada pela autora para buscar delinear o modo de os afro-religiosos "fazerem política". Parto, assim, da análise de Miranda para refletir sobre a presença afro-religiosa no espaço público, em um plano mais geral, e, especificamente, na mobilização dessas categorias pelos afro-religiosos na luta pela garantia de seus direitos. Nesse intento, mobilizo parte da literatura sobre o tema, bem como minha própria experiência de pesquisa sobre essa temática, observando como esses religiosos modificam a categoria política acionada em suas mobilizaçóes na medida em que tais ataques tornam-se mais violentos.

Palavras-chave: intolerância religiosa; racismo religioso; religiôes afro-brasileiras; "política dos terreiros".

${ }^{1}$ Como citar: MORAIS, Mariana Ramos de. Intolerância, racismo e genocídio religioso do povo negro: pensando sobre as categorias afro-religiosas da "política dos terreiros". Debates do NER, Porto Alegre, ano 21, n. 40, p. 137-162, 2021.

2 Doutora em Ciências Sociais e pesquisadora de Pós-Doutorado no Programa de Pós-Graduação em Antropologia Social do Museu Nacional da Universidade Federal do Rio de Janeiro, Laboratório de Antropologia do Lúdico e do Sagrado (Ludens), Brasil. E-mail: marianaramosdemorais@gmail.com. ORCID: https://orcid.org/0000-0002-1604-2366.

Debates do NER, Porto Alegre, ANo 2I, N. 40, P. I 37-I62, Ago./DeZ. 202 I 
INTOLERANCE, RACISM AND RELIGIOUS GENOCIDE AGAINST BLACK PEOPLE: THINKING ON THE AFRO-RELIGIOUS CATEGORIES IN THE "TERREIROS POLITICS"

\begin{abstract}
In this text, I present comments on the article "'Terreiro politics' against religious racism and 'christofascist' politics", by Ana Paula Mendes de Miranda. The comments focus on the three categories mobilized by the practitioners of Afro-Brazilian religions in their struggle to guarantee their rights in the face of to the intensification of attacks by Evangelical groups against Afro-Brazilian religions, namely: "religious intolerance", "religious racism" and "religious genocide of the black people". The proposal is to think about how these categories have been constituted in the "terreiro politics", an expression adopted by the author to delineate the way in which the practitioners of Afro-Brazilian religions "make politics". I start, therefore, from Miranda's analysis to reflect on the Afro-religious presence in public space and specifically on the mobilization of these categories by Afro-religious people in the struggle to guarantee their rights. In this attempt, I mobilize part of the literature about this them, as well as my own research experience, observing how these religious change the political category triggered in their mobilizations as such attacks become more violent.
\end{abstract}

Keywords: religious intolerance, religious racism, Afro-Brazilian religions, "terreiro politics"

Em 1997, era publicada a primeira edição da revista Debates do NER lançando a seguinte questão: Neopentecostais ou afro-brasileiros: quem vencerá esta guerra? Esse era o título do artigo de Ari Pedro Oro (1997) que inaugurou a série de discussóes propostas por este periódico do Núcleo de Estudos da Religiáo (NER) da Universidade Federal do Rio Grande do Sul (UFRGS). Decorridos vinte e quatro anos daquela edição, o presente número traz novamente em destaque evangélicos e afro-religiosos ${ }^{3}$ a partir

3 De acordo com as atuais normas ortográficas da língua portuguesa, a palavra "afro-religioso" - e suas flexóes de número e gênero - deve ser escrita sem o uso do hífen, adotando-se a grafia "afrorreligioso". No entanto, opto pela versão hifenizada para salientar o prefixo "afro-" enquanto um qualificativo de "religioso". Esse termo é usado neste texto para nomear os praticantes das religióes afro-brasileiras, observada sua pluralidade, sem fazer uma distinção entre aqueles que participam ou não de movimentos sociais; e para adjetivar o movimento social ou as práticas religiosas advindas desse grupo religioso.

Debates do NER, Porto Alegre, Ano 2 I, N. 40, P. I37-I62, Ago./DEZ. 202 I 
da abordagem proposta por Ana Paula de Mendes Miranda, no artigo $A$ "politica dos terreiros" contra o racismo religioso e as políticas "cristofascistas", sobre o qual apresento meus comentários ${ }^{4}$.

Para elaborar sua análise, Miranda recorre aos dados produzidos em suas pesquisas desde 2008, cujos resultados vêm sendo divulgados em diversas publicaçôes. Nessas pesquisas, a autora observa a maneira como os afro-religiosos se organizam no espaço público com vistas à reivindicação de seus direitos frente ao acirramento dos ataques de grupos evangélicos 5 . Ela concede especial atenção às dinâmicas de vitimização dos afro-religiosos, às suas estratégias de visibilidade, bem como ao tratamento e à administração institucional dos conflitos com os grupos evangélicos. Sua experiência de pesquisa se dá, principalmente, na capital do Rio de Janeiro (RJ), tendo também acompanhado açôes dos afro-religiosos em Brasília (DF), Aracaju (SE) e Maceió (AL).

Diferentemente de grande parte dos cientistas sociais que têm pesquisado os ataques evangélicos às religióes afro-brasileiras, Miranda não parte dos estudos da religião para desenvolver seus trabalhos. Ela constrói suas reflexôes a partir da "antropologia dos conflitos", tendo uma intensa atuação no campo da segurança pública ${ }^{6}$. Buscar compreender como as mudanças

4 Ao longo desses anos, os ataques de grupos evangélicos às religiōes afro-brasileiras foram abordados em outros momentos e de diferentes formas nas páginas do Debates do NER. A intenção aqui não é de recuperar toda a discussão já realizada sobre o tema neste periódico, mas salientar a diferença entre a cena informada por Ari Pedro Oro em 1997 e a que Ana Paula de Mendes Miranda nos apresenta agora em seu artigo, dado o agravamento desses ataques.

5 Uso neste texto a expressão "grupos evangélicos" de forma mais genérica, não indicando as denominaçóes que são protagonistas dos mencionados ataques. $\mathrm{Na}$ verdade, são variadas as denominaçóes, principalmente, vinculadas à vertente neopentecostal, que constitui a fase mais recente do movimento pentecostal, o que não exclui desse processo algumas igrejas mais antigas. Sobre o uso do termo "ataque" para nomear as investidas públicas de grupos evangélicos contra os afro-religiosos, sigo o proposto por Vagner Gonçalves da Silva (2007a).

${ }^{6}$ Conforme as informaçóes constantes de seu currículo apresentado na Plataforma Lattes do Conselho Nacional de Desenvolvimento Científico e Tecnológico (CNPq). Disponível em: http://lattes.cnpq.br/1955313077111684. Acesso em: 15 maio 2021. 
no campo religioso brasileiro incidem nas práticas afro-religiosas ou como as dinâmicas rituais afro-brasileiras são impactadas pelas crescentes investidas de grupos evangélicos não consta, portanto, dos seus objetivos. As questôes que animam suas pesquisas são de outra natureza, como informam as primeiras linhas do artigo focalizado nestes comentários: "Como a (in)tolerância religiosa afeta a constituição de subjetividades dos que são tolerados ao ponto de produzir resistência? Até que ponto um conflito entre grupos religiosos é uma tensão produtora de governamentalidade quando se explicitam as contradiçôes dos discursos em contraste com as práticas dos agentes do Estado?” (Miranda, 2021, neste número). Ela apresenta, assim, um outro viés para se pensar a relação entre evangélicos e afro-religiosos, renovando os estudos dedicados aos ataques dos primeiros contra os segundos e, de forma mais ampla, à presença afro-religiosa no espaço público.

Como se sabe, desde pelo menos os anos 1960 são registradas as investidas de grupos evangélicos contra as religiōes afro-brasileiras (Mariano, 2007). Se em um primeiro momento as açóes desses grupos incidiam principalmente no plano simbólico, elas passaram a envolver violência física contra os praticantes das religióes afro-brasileiras e seus locais de culto, os terreiros. Por vezes tratavam-se de agressóes verbais, noutras de depredação do patrimônio afro-religioso, que seguindo a legislação brasileira já deveriam ser enquadradas como ações criminosas, embora nem sempre tipificadas enquanto tal. Contudo, desde 2017, avolumam-se os casos de expulsão dos praticantes de seus terreiros e de destruição dos mesmos, além de registro de assassinatos de sacerdotes (Almeida, 2019). Nessas últimas açôes, observa-se a atuação de grupos evangélicos em intercessão com facçóes criminosas, indicando um agravamento dos ataques evangélicos às religiôes afro-brasileiras.

Esses ataques têm afetado a maneira como o movimento afro-religioso reformula seu modo de ação e também amplia sua atuação no espaço público para resguardar seus direitos, diuturnamente violados ${ }^{7}$. Uma mudança que

7 O movimento afro-religioso é entendido aqui como um movimento social formado por entidades representantes das religióes afro-brasileiras, que apresenta diferentes frentes de atuação. Essas frentes se modificaram ao longo dos séculos XX e XXI, mantendo como seu objetivo primeiro a busca pela garantia da prática religiosa de seus representados.

Debates do NER, Porto Alegre, ANo 2 I, N. 40, P. I 37-I62, Ago./Dez. 202 I 
se evidencia a partir da constituição de três categorias políticas mobilizadas por representantes desse movimento social, quais sejam: "intolerância religiosa", "racismo religioso" e "genocídio religioso do povo negro", conforme elencadas no artigo de Miranda. Essas categorias são o foco principal destes comentários. Interessa aqui a forma como elas têm sido formuladas e acionadas na "política dos terreiros", expressão adotada pela autora para delinear o modo de os afro-religiosos "fazerem política".

Parto, assim, da análise de Miranda para pensar sobre a presença afro-religiosa no espaço público, em um plano mais geral, e, especificamente, na mobilização dessas categorias pelos afro-religiosos na luta pela garantia de seus direitos. Para tanto, apoio-me em parte da literatura sobre o tema, bem como na minha própria experiência de pesquisa, observando como esses religiosos modificam a categoria política acionada em suas mobilizaçóes na medida em que tais ataques tornam-se mais violentos. A referência à discussão proposta em torno do artigo de Oro, datado de 1997, justifica-se, dessa forma, por ela contribuir para se pensar nas questóes levantadas por Miranda, neste número, devido à mudança do cenário que acompanha o cerne das duas análises, como será apontado nestes comentários.

\section{DA INÉRCIA À MOBILIZAÇÁo}

No artigo Neopentecostais ou afro-brasileiros: quem vencerá esta guerra?, Ari Pedro Oro (1997) descreve e analisa a cena afro-religiosa encontrada por ele no final dos anos 1990. Tomo esse artigo de Oro como um retrato de um momento, considerando os limites da cena informada pelo autor dado ao enquadramento proposto na sua análise e às imagens capturadas para embasar seus argumentos que, consequentemente, derivam da luz que lançou sobre os atores e que deles refletiu. Nele, o autor discorre sobre o significado da demonização das religióes afro-brasileiras por parte de grupos evangélicos, especialmente da Igreja Universal do Reino de Deus (IURD), e também procura "compreender a fraca reação por parte das religiôes vítimas 
das acusaçôes" (Oro, 1997, p. 11). Apesar de reconhecer que já haviam manifestaçōes de repúdio aos ataques evangélicos naquele momento, o que ele frisa em seu artigo é a relativa escassez e fragilidade dessas reaçôes ${ }^{8}$. Uma das seçōes do artigo, por exemplo, é dedicada inteiramente à "inércia das religiôes afro-brasileiras" face aos ataques evangélicos. Nas suas palavras:

É absolutamente desmesurada a constância e a insistência dos ataques desfechados diuturnamente pelas igrejas neopentecostais contra as religióes afro-brasileiras e o silêncio, ou respostas pálidas, quase ausência de reaçóes por parte destas últimas. E é importante saber que seus líderes e participantes de um modo geral possuem consciência das agressōes de que são vítimas. Então a pergunta se impóe: por que a não reação? (Oro, 1997, p. 22)

Oro informa, de pronto, que não há uma resposta única para a questâo levantada, mas várias justificativas que podem estar imbricadas umas nas outras. Com base em dados produzidos a partir da relaçáo estabelecida por ele com religiosos afro-brasileiros do Rio Grande do Sul, o autor destaca algumas dessas justificativas. A primeira seria o fato de os ataques serem dirigidos às religiốes afro-brasileiras de forma mais genérica e não diretamente ao praticante. Considerando, a partir de Reginaldo Prandi (1992), que essas religiôes são fortemente centradas no indivíduo, seus praticantes não pareciam se sentir atingidos por aqueles ataques, conforme Oro demonstrou com seus dados etnográficos.

Uma segunda justificativa seria a dificuldade de os afro-religiosos encaminharem açôes e campanhas no âmbito religioso, adotando a estratégia de "ataque" a símbolos religiosos evangélicos. A certeza de que as religióes afro-brasileiras seriam capazes de sobreviver às investidas evangélicas com base na sua experiência de resistência frente ao longo histórico de perseguição

8 Oro (1997, p. 12) menciona em nota que, na época, houve manifestaçốes de entidades do movimento negro e do movimento afro-religioso repudiando os ataques evangélicos, tal como passeatas, publicaçôes em jornais, formação de comitês, elaboraçáo de dossiês com as queixas e denúncias junto à polícia e à Justiça.

Debates do NER, Porto Alegre, ANo 2I, N. 4O, P. I37-I62, Ago./DeZ. 202 I 
e de repressão é apontada pelo autor como uma terceira justificativa. Como uma quarta justificativa, ele menciona o poder político secundário que as religióes afro-brasileiras ocupam na sociedade brasileira.

$\mathrm{Na}$ sequência, Oro cita duas justificativas que ele considera as mais significativas para se compreender a pouca mobilização afro-brasileira, no final dos anos 1990, diante dos vilipêndios lançados pelos neopentecostais: os mecanismos de apropriação e reelaboração neopentecostal de crenças e códigos simbólicos afro-religiosos presentes no universo de representação dos novos crentes; e o fato de as religióes afro-brasileiras não serem estruturadas a partir de um modelo que opera com poder centralizador, dada a autonomia dos terreiros que ainda mantêm uma rivalidade entre si. Essa dada autonomia dos terreiros incidiria na dificuldade de os afro-religiosos se organizarem institucionalmente para se defenderem dos ataques evangélicos. Tal posicionamento é partilhado por outros pesquisadores.

Entre aqueles pesquisadores que comentaram o artigo de Oro no número inaugural do Debates do NER, Maria Clara Ramos Nery (1997), por exemplo, reitera essa dificuldade e questiona: "Como aglutinar forças se o repertório professado não permite esta aglutinação?" (Nery, 1997, p. $84)^{9}$. Esse seria um desafio posto aos religiosos afro-brasileiros uma vez que, conforme a autora, o universo de representaçôes afro é fragmentário. Cecilia Loreto Mariz (1997), em texto que também compôs o referido dossiê, coaduna, em parte, com o exposto por Oro. Para a autora, "a aparente inércia do povo de santo em relação aos ataques dos neopentecostais se explica mais por sua cosmovisão do que por sua fragilidade política e social" (Mariz, 1997, p. 101).

A ausência de uma proposta ética universal entre os afro-religiosos lembrando que se trata de um grupo heterogêneo formado por adeptos de diferentes religióes, como candomblé, umbanda, batuque, jurema, tambor

9 Ressalto que nenhum comentário ao artigo de Oro (1997) póe em questão a relativa inércia dos afro-religiosos frente aos ataques de grupos evangélicos nem a dificuldade de os primeiros se organizarem institucionalmente.

Debates do NER, Porto Alegre, ANo 2I, N. 4O, P. I 37-I62, AGo./DeZ. 202 I 
de mina, xangô - seria, para Mariz, um obstáculo à construção de uma unidade entre eles. Esse obstáculo, no entanto, náo seria capaz de impedir a organizaçáo dos afro-religiosos. Como bem ressalta a autora, o próprio Ari Pedro Oro apontava em seu artigo de 1997 que a guerra promovida por grupos evangélicos contra as religióes afro-brasileiras poderia contribuir para a sua institucionalizaçáo. Essa guerra estaria promovendo uma outra interessante mudança, conforme também observa Mariz (1997, p. 102): o fato de as religióes afro-brasileiras passarem a ser representadas na mídia como "vítimas" em vez de serem acusadas de charlatanismo e de ludibriarem os mais pobres. Ainda segundo a autora, essas atribuiçôes, no fim da década de 1990, estavam sendo conferidas aos evangélicos.

Quando da publicação do referido artigo de Oro, observava-se o arrefecimento de uma experiência associativa adotada pelos afro-religiosos. Trata-se do movimento federativo que teve uma expressiva atuaçáo em defesa das religióes afro-brasileiras, especialmente a partir da década de 1950. Naquele momento, a Igreja católica liderava uma intensa campanha contra as religióes afro-brasileiras, que também eram perseguidas pelo Estado brasileiro (Negrão, 1996). Os grupos evangélicos ainda não figuravam como protagonistas dos ataques àquelas religiôes. No decorrer da segunda metade do século XX, porém, elementos referentes ao universo afro-religioso foram sendo incorporados a uma dada ideia de cultura brasileira e, pouco a pouco, as religiōes afro-brasileiras foram ganhando legitimidade social, embora persistisse o preconceito contra elas.

O movimento federativo é em grande parte atrelado aos umbandistas. Praticantes do candomblé, no entanto, também se reuniam em "federaçôes". A Federação Nacional do Culto Afro-Brasileiro fundada em 1946, em Salvador (BA), é um exemplo ${ }^{10}$. Em comum, essas entidades tinham o

10 Quando da sua fundação, em 1946, a Federação Nacional do Culto Afro-Brasileiro foi nomeada Federação Baiana do Culto Afro-Brasileiro. A mudança de nome ocorreu em 2002. 
intento de garantir o direito de seus representados praticarem suas religióes ${ }^{11}$. $\mathrm{E}$, nesse intento, acabavam definindo parâmetros para estabelecer o que era ou não considerado uma prática religiosa afro-brasileira. Fato questionado por parte dos praticantes dessas religiōes que, como lembrado por Oro, não são estruturadas a partir de um modelo que opera com poder centralizador, já que os terreiros mantêm uma dada autonomia entre si.

Estudos que tiveram como foco o movimento federativo umbandista apontaram também para a dificuldade de os terreiros se associarem em função da própria autonomia, que, investida de autoridade, era conferida a cada chefe de terreiro ou a cada sacerdotisa e sacerdote (Birman, 1985; Brown, 1985; Negrão, 1996). Fato que também era entendido como um empecilho para que os afro-religiosos elegessem representantes nas casas legislativas. Essa dificuldade não é restrita à umbanda. Por motivos semelhantes aos observados no movimento federativo umbandista, a citada Federação Nacional do Culto Afro-Brasileiro também teve a sua legitimidade questionada (Santos, 2005, p. 159). Justamente quando essa experiência associativa dos afro-religiosos - o movimento federativo - parecia se esgotar, os ataques evangélicos às religióes afro-brasileiras começaram a ganhar outras dimensóes.

Nos anos 1990, parte dos estudos que se dedicavam a esses ataques os definiam nos termos de "conflito religioso" (Soares, 1990), de "guerra religiosa" (Soares, 1993) ou de "guerra espiritual" (Corten, 1996), como mencionado por Oro (1997). Na época, havia um entendimento de que evangélicos e religiosos afro-brasileiros concorriam entre si no chamado mercado religioso uma vez que seus adeptos advinham do mesmo estrato populacional, das comunidades periféricas. Nem sempre era explicitada a

11 Como é sabido, ao longo do século XX são diversos os registros de perseguição e de repressão às religióes afro-brasileiras pelo Estado brasileiro, que se valeu de suas forças policiais e da adoção de normas legais que afetavam diretamente a prática dessas religiôes. Nas duas últimas décadas daquele século e na primeira deste século XXI, porém, essa postura parecia se modificar diante do contexto político brasileiro que apontava para a ampliação dos direitos democráticos. No entanto, trata-se de uma situação instável, ainda mais com a ascensão de forças conservadoras no país.

Debates do NER, Porto Alegre, ANo 2I, N. 4O, P. I 37-I62, AGo./DeZ. 202 I 
relação desigual que existia entre esses dois grupos religiosos. Vale lembrar que foram os evangélicos que, desde o princípio, se lançaram contra as religiôes afro-brasileiras, buscando demonizá-las e difundindo suas ideias não apenas nos seus ambientes de culto, mas também usando de instrumentos midiáticos aos quais os afro-religiosos não tinham o mesmo acesso ${ }^{12}$.

Como já mencionado, Oro reconhecia que houve manifestaçóes de repúdio aos ataques evangélicos às religióes afro-brasileiras. Essas manifestaçóes adivinham de entidades do movimento negro e do movimento afro-religioso e eram expressas em passeatas, em jornais, na formação de comitês, na elaboração de dossiês e em denúncias junto à polícia e à Justiça (1997, p. 12). Aliás, o apelo à esfera jurídica seria, conforme o autor, uma estratégia de defesa dos afro-religiosos, embora ele observasse sua ineficácia naquelas circunstâncias. Dentre essas manifestaçôes, poderia se considerar a elaboração do dossiê "Guerra santa fabricada" que documentou invasóes e agressôes a terreiros do Rio de Janeiro. A palavra "guerra" surgia também em uma outra expressão que fazia referência aos ataques evangélicos às religiôes afro-brasileiras, dessa vez, sendo adotada pelos próprios afro-religiosos. Esse dossiê foi elaborado por sacerdotisas e sacerdotes daquele estado e protocolado junto ao Ministério Público Federal, em Brasília, em 1989. Esse ato é reivindicado por uma entidade do movimento afro-religioso constituída em 2011, o Fórum Nacional de Segurança Alimentar e Nutricional dos Povos Tradicionais de Matriz Africana (FONSANPOTMA), como sendo a primeira vez em que uma denúncia sobre as violaçóes cometidas por grupos evangélicos teria chegado formalmente ao conhecimento do Estado brasileiro (Almeida, 2019, p. 66).

Esse dossiê foi entregue ao Ministério Público Federal apenas um ano após a promulgação da Constituição Federal de 1988, a dita Constituição

12 Por parte dos afro-religiosos também há o uso de instrumentos midiáticos para difundirem suas religiôes, como jornais vinculados às suas entidades representativas, programas de rádio e, mais recentemente, as redes sociais. No entanto, eles não chegam a ser proprietários de emissoras de rádio e televisão nem de periódicos, como é o caso de grupos evangélicos.

Debates do NER, Porto Alegre, ANo 2 I, N. 40, P. I37-I62, Ago./DeZ. 202 I 
cidadã. Naquele momento, já se observava um estreitamento de relaçôes entre militantes do movimento negro e praticantes das religióes afro-brasileiras, tanto pelo interesse dos primeiros em aderir àquelas religióes quanto de ambos na construção de uma agenda conjunta em que o combate ao racismo era a pauta primeira ${ }^{13}$. O Centro Nacional de Africanidade e Resistência Afro-Brasileira (Cenarab) é fruto dessa aproximação. Fundado em 1992 e ainda em atividade, o Cenarab é considerado uma entidade do movimento negro pela defesa das religióes afro-brasileiras, associando essa pauta à luta contra o racismo, tal como consta no boletim informativo da entidade:

Uma das finalidades do Cenarab é a articulação e a mobilização dos Vivenciadores das Culturas e Religiôes de Matriz Africana (Candomblé de: Angola, Congo, Ketú, Ijexá, Efon, Nagô, Gege-Nagô, Umbanda, Xangô, Tambor de Mina, Mina-Gêge, Xambá, Pajelança, Omolokô, Catimbó, etc.) em busca da unidade e organicidade política nacional dos mesmos, para fazer frente ao processo secular e comum de marginalização, preconceitos, discriminaçóes, estigmas e estereótipos disseminados na sociedade brasileira. (citado por Cardoso, 2001, p. 174)

Chamo a atenção para o intento dessa entidade de reunir diferentes modalidades de religiôes afro-brasileiras com vistas à organização política de seus praticantes. Não estava ali, porém, uma menção explícita aos ataques evangélicos às religiōes afro-brasileiras que, além de definidos a partir das noçôes de "guerra" e de "conflito", passaram a ser referidos em uma outra expressão adotada nos estudos sobre o tema como também entre os próprios afro-religiosos. Ari Pedro Oro já enunciava em seu texto de 1997 que tais ataques eram "uma demonstração explícita de intolerância religiosa" (Oro,

13 A relação do movimento negro com as religióes afro-brasileiras nem sempre foi de proximidade. A presença de uma vertente marxista no movimento social que se organizava nos anos 1970, por exemplo, era um entrave à aproximação dos militantes negros com os terreiros (Santos, 2005). No entanto, ainda naquela década, quando do surgimento do Movimento Negro Unificado, havia também um entendimento de que os terreiros eram locais da resistência negra e, portanto, de luta contra o racismo (Morais, 2018).

Debates do NER, Porto Alegre, ANo 2I, N. 40, P. I 37-I62, Ago./DeZ. 202 I 
1997, p. 10). Foi justamente essa expressão, "intolerância religiosa”, que passou a ser recorrentemente usada, a partir do início dos anos 2000, para classificar esses ataques contra as religiōes afro-brasileiras (Silva, 2007a). E, mais do que isso, a expressão "intolerância religiosa" passou a ser acionada enquanto uma categoria política na luta dos afro-religiosos por seus direitos ${ }^{14}$.

\section{INTOLERÂNCIA RELIGIOSA}

Foi contra a "intolerância religiosa”, por exemplo, que os afro-religiosos se mobilizaram após a morte de Mãe Gilda, a ialorixá baiana Gildásia dos Santos e Santos, que teve sua imagem exposta sem autorização em uma publicação da Igreja Universal do Reino de Deus que a caluniava e infamava as religiôes afro-brasileiras. Mãe Gilda faleceu em 21 de janeiro de 2000. Naquele mesmo ano, na Bahia, foi organizado o Movimento Contra a Intolerância Religiosa; no Rio de Janeiro, formou-se, em 2001, o Movimento Diálogo Inter-Religioso contra a Intolerância Religiosa e pela Paz, e no Rio Grande do Sul, em 2002, foi criada a Comissão de Defesa das Religióes Afro-Brasileiras. Mobilizaçóes semelhantes ocorreram em outras cidades a partir do caso de Mãe Gilda, mas não se encerrando nele, uma vez que os ataques oriundos de grupos evangélicos contra as religiōes afro-brasileiras se acirraram. Essas mobilizaçóes repercutiram para além dos meios afro-religiosos, levando à instituição, em 2007, do Dia Nacional de Combate à Intolerância Religiosa.

O falecimento de Mãe Gilda é entendido aqui como um "evento crítico", seguindo Renata de Castro Menezes (2017), a partir do proposto por Bruce Kapferer (2010). Uma situação de crise, segundo esse autor, tem a capacidade de revelar forças em interação no mundo social. Ou, como interpreta Menezes, os "eventos críticos" não somente desvelam forças e padrôes já existentes, pois

${ }^{14}$ Nos limites destes comentários não cabe uma discussão de cunho mais teórico sobre as noçôes de "tolerância” e "intolerância”, que é abordada brevemente por Miranda (2021) e também pode ser encontrada em outros autores, como Mariano (2007).

Debates do NER, Porto Alegre, Ano 2 I, N. 40, P. I37-I62, Ago./DEZ. 202 I 
tratam-se também de momentos que "permitem a irrupção do novo, do até então impensável, do surpreendente, do desestabilizador” (Menezes, 2017, p. 2). Os atos públicos protagonizados pelos afro-religiosos após o falecimento de Mãe Gilda, tendo por mote a luta contra a "intolerância religiosa”, podem ser considerados, nesse caso, como algo inesperado.

De fato, o "povo de santo" sempre esteve na "rua", seja para saudar suas divindades e entidades ou para fazer das festas religiosas nos espaços públicos também um ato político. A novidade dos atos contra a "intolerância religiosa" estava na capacidade de essa pauta reunir diferentes agentes do movimento afro-religioso, já que se trata de um meio mais marcado por "dissidências e contraposição do que por aglutinação em torno de entidades de representação coletiva”, como lembrado por Vagner Gonçalves da Silva (2007a, p. 22). É datada de 2007, inclusive, uma coletânea organizada por Silva (2007b) sob o título Intolerância religiosa: impactos dos neopentecostalismo no campo religioso afro-brasileiro. Nela, já estava indicada uma mudança, ainda que incipiente, na maneira como os afro-religiosos se mobilizavam para enfrentar os ataques evangélicos:

Os casos de intolerância, antes apenas episódios e sem grandes repercussóes, hoje se avolumaram e saíram da esfera das relaçóes cotidianas menos visíveis para ganhar visibilidade pública, conforme atestam as frequentes notícias de jornais que os registram em inúmeros pontos do Brasil. Igualmente, a reação a esses casos, antes apenas um esboço isolado e tímido de algumas vítimas, agora se faz em termos de processos criminais levados adiante por pessoas físicas ou instituiçôes públicas como ONGs e até mesmo a Promotoria Pública. (Silva, 2007a, p. 10)

Esse contexto descrito por Silva pode ter sido o encontrado por Miranda quando iniciou suas pesquisas relacionadas às mobilizaçóes dos afro-religiosos frente aos ataques evangélicos. A autora constrói uma cena - que também tem seus limites como toda e qualquer interpretação do social - em que os afro-religiosos protagonizam açóes em defesa de seus direitos diante do agravamento dos ataques evangélicos. Dentre as ações descritas por ela, constam mobilizaçôes com vistas à atuação no âmbito do executivo, do legislativo e 
do judiciário. Os afro-religiosos não apenas organizam atos públicos, eles também se organizam institucionalmente, como defende a autora. Essa é a base para que ela fundamente um importante argumento de seu texto: de que existe uma forma própria de os afro-religiosos "fazerem política" que é denominada por ela como a "política dos terreiros".

Esse modo de fazer política emerge, segundo Miranda, no enfrentamento à negação de direitos aos religiosos afro-brasileiros. Para tanto, esses religiosos construíram alianças entre si, orientados, primeiramente, pelas relaçôes advindas de suas linhagens iniciáticas. Em um segundo momento, eles buscaram parcerias com organizaçóes públicas e/ou movimentos sociais. E, a partir de então, teriam se estruturado tendo como eixo a luta por reconhecimento de sua diversidade "étnico-racial-religiosa" e dos pertencimentos sociopolíticos de sujeitos marginalizados. Dessa forma, argumenta a autora, os afro-religiosos constituíram um ativismo religioso específico. Eles não demandam a inserção de suas crenças e valores religiosos na normatividade jurídica ou nas políticas públicas. Eles reivindicam do Estado, isso sim, o seu direito de existir e denunciam seus agressores, que estariam agindo motivados pelo preconceito racial.

Miranda está, dessa forma, se opondo àqueles que afirmam que o "povo de santo" não se organiza politicamente ou, como informa em outro ponto do seu texto, que esses "religiosos não se unem". Decerto, em estudos das ciências sociais sobre as religiôes afro-brasileiras - não se restringindo à antropologia - essa representação, construída empiricamente, se faz presente. Miranda, contudo, não explicita quem seriam os autores do posicionamento ao qual se opóe. Penso que recuperar parte dessa literatura pode contribuir para refletir sobre a "política dos terreiros" proposta pela autora nesta segunda década dos anos 2000. Dentro do meu repertório, conforme já exposto nestes comentários, os posicionamentos de que os afro-religiosos têm dificuldade para se organizar politicamente localizam-se em um tempo passado, apesar de meus dados etnográficos apontarem que os conflitos internos ainda alimentam dissensos entre eles. Esses conflitos, por sua vez, não impedem que os mesmos se unam em determinados momentos, especialmente na 
luta contra os ataques evangélicos, classificados, inicialmente, como atos de "intolerância religiosa" 15 .

A expressão "intolerância religiosa", como dito, passou a ser tomada pelos afro-religiosos como uma categoria política na luta por seus direitos. A autora considera que essa categoria "expressa experiências em situações de vitimização por preconceito e discriminação, provocada por um pertencimento identitário - étnico-racial e religioso, provocado principalmente devido ao crescimento de conflitos envolvendo grupos com religiosidade de perfil evangélico-pentecostal” (Miranda, 2021, neste número). Está explícita, assim, a relação entre o crescimento dos ataques evangélicos e o acionamento da categoria "intolerância religiosa" por parte dos afro-religiosos. Noto que, para a autora, está incutida nessa categoria um pertencimento identitário de cunho "étnico-racial e religioso", mesmo que a expressão "intolerância religiosa” em si não o evoque.

Apesar de os afro-religiosos terem conquistado um relativo destaque no espaço público ao articularem sua luta pela garantia do direito de praticar suas religiôes a partir da ideia do combate à "intolerância religiosa”, essa categoria passou a ser questionada por parte desse movimento social. Como pontua Miranda (2021, neste número), com o agravamento dos ataques evangélicos, essa categoria se mostrou insuficiente para a defesa dos afro-religiosos. Essa insuficiência tem uma questão prática: a dificuldade de se criminalizar os atos classificados como "intolerância religiosa”, uma vez que a "intolerância religiosa” não é tipificada como crime na legislação brasileira (Mariano, 2007). Essa questão está imbricada a uma outra, de cunho semântico, conforme indicado pelos próprios afro-religiosos.

${ }^{15}$ Menciono aqui um exemplo: a Federação Umbandista do Estado de Minas Gerais, fundada nos anos 1950, passou a denominar-se Associação de Umbanda e Candomblé do Estado de Minas Gerais, em 2008, no intento de abarcar essas duas religióes majoritárias no campo afro-religioso mineiro. No entanto, tal associação não manteve a ativa atuação da antiga "federação”. Alguns dos seus integrantes formaram a Reuniāo Umbandista Mineira, congregando umbandistas, como destacado no nome da entidade. No entanto, existem integrantes desta entidade que participam das atividades do Centro Nacional de Africanidade e Resistência Afro-Brasileira (Cenarab), que não está vinculado a uma modalidade afro-religiosa específica.

Debates do NER, Porto Alegre, ANo 2 I, N. 40, P. I 37-I62, Ago./DeZ. 202 I 


\section{RACISMO RELIGIOSO}

Em 2009, Makota Valdina e Mãe Beata de Yemonjá afirmaram: "Não queremos ser toleradas! Queremos ser respeitadas!"16. Makota Valdina e Mãe Beata demandavam por respeito enquanto mulheres negras que evocavam, seja dentro ou fora de seus espaços de culto, uma tradição legada por seus antepassados africanos. As duas participaram ativamente das articulaçóes dos afro-religiosos na política pública racial. Especialmente a partir de 2003, quando iniciou o primeiro mandato do presidente Luiz Inácio Lula da Silva, a atuação em políticas públicas que requerem a participação popular na sua elaboração e na sua execução passou a ser um caminho para os afro-religiosos lutarem por seus direitos (Gomes, 2010; Morais, 2012, 2018; Cordovil, 2014) ${ }^{17}$. Essa experiência contribuiu para que eles aprendessem uma gramática cívica que fundamenta a luta por direitos e também a produção das políticas públicas. Com isso, passaram a manusear essa gramática adotando seus próprios termos.

Foi Makota Valdina, por exemplo, quem transformou em "palavra dita” - que nas religiōes afro-brasileiras é imbuída de força, de energia - um entendimento sobre "intolerância religiosa" construído coletivamente por afro-religiosos que se reuniram desde 2011 junto à Secretaria de Políticas de Promoção da Igualdade Racial (Seppir) com a finalidade de elaborar o I Plano de Desenvolvimento Sustentável para Povos e Comunidades Tradicionais de Matriz Africana. Em julho de 2013, em Brasília, na Plenária Nacional dos Povos Tradicionais de Matriz Africana, uma etapa da III Conferência

${ }^{16}$ Foi Wanderson Flor do Nascimento (2017, p. 55) que creditou essas frases às duas sacerdotisas. Mas essas frases foram, e continuam a ser, entoadas por outros afro-religiosos críticos à categoria "intolerância religiosa”. Para um debate sobre a forma como as religiōes afro-brasileiras foram mobilizadas no âmbito da política racial brasileira, ver Morais (2018).

17 Vale lembrar que esse não é o único caminho escolhido pelos afro-religiosos visando a defesa de seus direitos e também o enfrentamento aos ataques evangélicos. Eles também têm apelado à Justiça (Oro, 2007; Silva Jr., 2007), buscado alianças junto a parlamentares ditos progressistas (Almeida, 2019) e organizado atos públicos para denunciar as agressóes das quais são vítimas (Silva, 2007a; Miranda, 2010). 
Nacional de Igualdade Racial, Makota Valdina leu, em público, um longo texto em que constava a seguinte definição para "intolerância religiosa":

Intolerância Religiosa - expressão que não dá conta do grau de violência que incide sobre os territórios e tradiçôes de matriz africana. Esta violência constitui a face mais perversa do racismo, por ser a negação de qualquer valoração positiva às tradiçóes africanas, daí serem demonizadas e/ou reduzidas em sua dimensão real. Tolerância não é o que queremos, exigimos sim respeito, dignidade e liberdade para SER e EXISTIR. (Lideranças... 2013)

Essa definição coloca em relevo a violência perpetrada contra as religióes afro-brasileiras, que estaria vinculada ao racismo, sendo "a face mais perversa" dele. Adota-se, assim, a ideia de que o racismo contra os negros é transposto para as religióes afro-brasileiras. Essa ideia foi construída aos poucos a partir da relação entre os movimentos negro e afro-religioso (Morais, 2018). É com base nela que os afro-religiosos constituíram uma outra categoria política mobilizada por eles na luta por seus direitos: a categoria "racismo religioso", como tenho observado em minhas pesquisas, coadunando com o proposto por Miranda. Ao mesmo tempo em que a expressão "racismo religioso" classifica as agressôes às religióes afro-brasileiras, ela também opera como um dispositivo jurídico e discursivo na luta dos afro-religiosos por seus direitos, acionando, assim, tal expressão enquanto uma categoria política.

A categoria "racismo religioso" passa a ser mobilizada pelos afro-religiosos quando há um agravamento dos ataques evangélicos às religióes afro-brasileiras, como bem observa Miranda. Não por acaso, algumas definiçóes de "racismo religioso" apontam que essa modalidade de racismo seria algo mais violento do que a "intolerância religiosa", além de se tratar de algo direcionado às religiốes que carregam heranças africanas (Flor do Nascimento, 2017; Deus, 2019; Rufino; Miranda, 2019; Nogueira, 2020).

Como tenho destacado (Morais; Jayme, 2017; Morais, 2018), os afro-religiosos, no âmbito das políticas públicas, têm associado suas práticas a uma dada noção de "cultura", tal como evidenciado na construção da categoria "povos e comunidades tradicionais de matriz africana" que passou a substituir 
expressōes como "religiōes de matriz africana" ou "comunidades de terreiro", que, diferentemente, fazem referência direta a um pertencimento religioso. Além de acionar um entendimento dado a essas religióes mais afeito à ideia de cultura no seu viés antropológico, a categoria "povos e comunidades tradicionais de matriz africana" reforça seu caráter "étnico", que não seria restrito a uma modalidade apenas, mas a uma pluralidade, desde que devidamente reconhecidas e/ou reivindicadas suas heranças africanas.

A construção da categoria "racismo religioso" ocorre em paralelo à construção da categoria "povos e comunidades tradicionais de matriz africana", quando afro-religiosos de todas as regiôes do país se reuniam na esfera federal para discutir políticas públicas de diferentes áreas. Interessante notar que, enquanto a categoria "povos e comunidades tradicionais de matriz africana" tenta se esvair do caráter religioso, a categoria "racismo religioso" recupera essa condiçấo, que é justamente o que dá sustentação para que ataques às religióes afro-brasileiras advindos de grupos evangélicos possam ser tipificados enquanto crime.

Dois documentos legais são importantes nesse contexto, uma espécie de preâmbulo para a formulação da categoria "racismo religioso": a lei 7.716, de 1989 e o Estatuto da Igualdade Racial, de 2010 (BRASIL, 2010). O primeiro documento, a lei 7.716, conhecida como Lei Caó, especifica quais são os "crimes resultantes do preconceito de raça ou de cor", um complemento à criminalização do racismo já prevista na Constituiçáo. Uma alteraçấo nessa lei, datada de 1997, determina que, para além dos "crimes resultantes do preconceito de raça ou de cor", devem também ser punidos os "crimes resultantes de discriminação ou preconceito" de "etnia, religiáo ou procedência nacional" ${ }^{18}$. Destaco a inclusão do termo "religiáo", que também consta do Estatuto da Igualdade Racial que, em vez que uma menção genérica ao termo, contempla de forma específica as religiôes afro-brasileiras no capítulo "Do direito à liberdade de consciência e de crença e ao livre exercício dos cultos religiosos", conforme expresso nos artigos 24,25 e 26.

18 Vale lembrar que não são apenas os afro-religiosos que buscam amparo da legislação sobre o racismo para buscar garantir o seu direito à prática religiosa (Silva Jr., 2007).

Debates do NER, Porto Alegre, Ano 2 I, N. 40, P. I 37-I62, Ago./DeZ. 202 I 
Interessante notar que no Estatuto da Igualdade Racial adota-se expressôes como "cultos religiosos de matriz africana", "religiosidade de matriz africana", "religióes de matriz africana”, ou seja, é explícita a afirmação das religiōes afro-brasileiras como "religião". É sob essa condição que tais religiôes têm o amparo legal para se defenderem no campo jurídico contra os ataques de grupos evangélicos. No entanto, ter o amparo legal não é garantia de ganho de causa. Etnografias sobre o enfrentamento dos afro-religiosos a esses ataques no campo jurídico têm demonstrado como é longo e tortuoso o caminho desde o ato de violência contra um praticante de alguma religião afro-brasileira e a sua classificação como crime pelos operadores do direito. Um caminho nem sempre iniciado pelas vítimas, muitas vezes por descrédito no sistema que deveria lhes assegurar liberdade para praticarem sua religião (Miranda, 2010; Almeida, 2019).

\section{GENOCÍDIO RELIGIOSO DO POVO NEGRO}

Além do campo jurídico, a categoria "racismo religioso" consta também, como mencionado, nas políticas públicas. Nos documentos públicos relativos à Política Nacional de Promoção da Igualdade Racial, a expressão "racismo religioso" surge em 2018, na compilação das propostas aprovadas na IV Conferência de Promoção da Igualdade Racial (BRASIL, 2018) ${ }^{19}$. Muitas delas demandam a criação de estruturas estatais que possam lidar com os casos de "racismo religioso". E, junto a essa expressão, uma outra é mencionada: "genocídio dos povos e comunidades tradicionais". Essa última expressão passa a ser adotada como um reflexo do recrudescimento dos ataques evangélicos às religiôes afro-brasileiras, como enfatiza Miranda (2021, neste número). Esses ataques passaram até mesmo a ser considerados "atentados" dada a

19 Noto que as mobilizaçôes dos afro-religiosos no âmbito das políticas públicas foram interrompidas após o início do governo do presidente Jair Bolsonaro que está em consonância com as forças conservadoras que têm posicionamentos contrários à uma ideia de nação plural em que os afro-religiosos poderiam ser contemplados em seus direitos.

Debates do NER, Porto Alegre, ANo 2I, N. 40, P. I 37-I62, AGo./DeZ. 202 I 
violência física contra os praticantes dessas religiôes, vítimas de assassinatos, e aos seus locais de culto, que chegam a ser destruídos, por integrantes de grupos evangélicos associados a facçóes criminosas (Almeida, 2019).

A categoria "genocídio dos povos e comunidades tradicionais" remete, a um só tempo, à noção de "genocídio do povo negro", cunhada por Abdias do Nascimento, como destacado no artigo de Miranda, e à categoria "povos e comunidades tradicionais de matriz africana". "Genocídio dos povos e comunidades tradicionais" é uma categoria nova, que apresenta variaçóes, como "genocídio religioso do povo negro". A inclusão do termo "religioso" nessa variante indica uma aproximação com a ideia de "racismo religioso", no que tange ao acionamento dos dispositivos jurídicos, e, ao mesmo tempo, exacerba o agravamento da violência para com os afro-religiosos.

O uso das categorias "racismo religioso" e "genocídio dos povos e comunidades tradicionais"/"genocídio religioso do povo negro", portanto, não é unânime. Nesses dois casos, aqueles que acionam tais categorias precisam assumir um pertencimento "étnico-racial" junto ao pertencimento religioso. Isso nem sempre ocorre, como é citado por Miranda. Por mais que o caráter étnico das religiôes afro-brasileiras seja destacado desde os primeiros estudos sobre essas religióes e mesmo reivindicado por seus adeptos, é bom lembrar que, como afirma Reginaldo Prandi (1990), tratam-se de religióes universais ou abertas a todos.

No momento em que o movimento negro reforça sua luta antirracista, colocando a branquitude em questão, a mobilização dessas duas categorias pode, assim, encontrar entraves junto a esse movimento social que tem sido um importante aliado dos afro-religiosos no espaço público. Como apontam Leila Amaral e Vagner Gonçalves da Silva (1993, p. 119), "para conviver numa religiáo tida como de negros, os brancos fazem um discurso em que negros e brancos aparecem como iguais (podendo compartilhar dos mesmos valores religiosos ao afirmar que o axé náo tem cor)". No entanto, sendo o racismo parte de nossa estrutura societária, ele se faz também presente nos terreiros, distinguindo negros e brancos e, dessa forma, colocando em xeque, justamente, a afirmativa de que o "axé não tem cor".

A categoria "intolerância religiosa" continua a ser adotada por parte do movimento afro-religioso que também mobiliza outras categorias, como 
terrorismo religioso, no enfrentamento aos ataques evangélicos. Visto que são variadas as religióes afro-brasileiras, é plural o movimento social delas emanado. Variadas são, assim, as entidades representativas desse movimento que, no artigo de Miranda, parecem se congregar para fazer frente a um inimigo comum. Certamente, uma das experiências citadas pela autora, o Fórum Nacional de Segurança Alimentar e Nutricional dos Povos Tradicionais de Matriz Africana (FONSANPOTMA), tem apresentado uma capacidade de reunir afro-religiosos de diferentes vertentes e localidades do país. Talvez seja por isso que a autora é tão veemente em seu posicionamento contrário a quem afirma que os afro-religiosos não se unem.

Conforme mencionei, a literatura tem apontado para a dificuldade dos terreiros se associarem devido à sua própria autonomia, que é diferente de eles não se associarem. De fato, desde os anos 1930 os terreiros buscam se associar institucionalmente, citando aquelas que seriam as primeiras entidades representativas do movimento afro-religioso: a União das Seitas Afro-Brasileiras da Bahia, criada em 1937, e a União Espírita da Umbanda do Brasil, de 1939. E, desde então, também se dissociam e criam outras formas de se congregarem para lutar pela defesa de suas práticas religiosas. O FONSANPOTMA não é a primeira experiência de reunião de diferentes modalidades de culto. O Cenarab, citado nestes comentários, e mesmo o Instituto Nacional da Tradição e Cultura Afro-Brasileira (Intecab), fundado nos anos 1980, já tinham essa proposta. Esse último tem inclusive como lema: "União na diversidade" ${ }^{20}$. Ao mesmo tempo em que se observa essas tentativas de atuação conjunta, há também entidades que visam reforçar uma identidade ritual, como é o caso das entidades representativas do candomblé de tradição banta que começam a ser constituídas a partir dos anos 1990 (Morais, 2018) ${ }^{21}$.

20 Para uma análise sobre a formação do Intecab, ver Capone (2004).

21 Como exemplos das entidades representativas do candomblé de tradição banta, cito: a Associação Cultural de Preservação do Patrimônio Bantu (Acbantu), o Movimento Nação Bantu (Monabantu), a Confederação das Tradiçóes e Culturas Bantu no Brasil (Cobantu) e Instituto Latino Americano de Tradiçóes Afro Bantu (Ilabantu). 
A literatura à qual fiz referência estava baseada em um outro momento, quando grupos evangélicos ainda não se demonstravam tão ameaçadores à continuidade das práticas afro-religiosas. A violência com que esses grupos passaram a investir contra as religióes afro-brasileiras, táo bem demonstrado no artigo de Miranda, pode, de fato, ser um impulso a novas experiências associativas que busquem suplantar as diferenças e as divergências entre os afro-religiosos na luta por seus direitos ainda previstos na legislação brasileira.

\section{REFERÊNCIAS}

ALMEIDA, Rosiane Rodrigues de. A luta por um modo de vida: as narrativas e estratégias de enfrentamento ao racismo religioso dos membros do FONSANPOTMA. 2019. Tese (Doutorado em Antropologia) - Universidade Federal Fluminense, Niterói, 2019.

AMARAL, Rita de Cássia; SILVA, Vagner Gonçalves da. A cor do axé: brancos e negros no candomblé de São Paulo. Estudos Afro-Asiáticos, Rio de Janeiro, v. 25, p. 99-124, 1993.

BIRMAN, Patrícia. Registrado em cartório, com firma reconhecida: a mediação política das federaçôes de umbanda. In: BROWN, Diana et al. Umbanda e politica. Rio de Janeiro: Iser/Marco Zero, p. 80-121. 1985.

BRASIL. Lei n. ${ }^{\circ} 12.288$, de 20 de julho de 2010. Institui o Estatuto da Igualdade Racial; altera as Leis n. ${ }^{\circ} \mathrm{s} 7.716$, de 5 de janeiro de 1989, 9.029, de 13 de abril de 1995, 7.347, de 24 de julho de 1985, e 10.778, de 24 de novembro de 2003. Diário Oficial da União, Brasília, DF, 21 jul. 2010. Disponível em: https://www.planalto.gov.br/ccivil_03/_ato2007-2010/2010/ lei/l12288.htm. Acesso em: 15 maio. 2021.

BRASIL. IV Conferência Nacional de Promoção da Igualdade Racial. Propostas aprovadas. Brasília, DF, 2018. 
BROWN, Diana. Uma história da umbanda no Rio. In: BROWN, Diana et al. Umbanda e política. Rio de Janeiro: Iser/Marco Zero, 1985. p. 9-42. CAPONE, Stefania. A busca da África no candomblé: tradição e poder no Brasil. Rio de Janeiro: Contra Capa Livaria/Pallas, 2004.

CARDOSO, Marcos Antônio. O Movimento Negro em Belo Horizonte: 19781998. 2001. Dissertação (Mestrado em História) - Universidade Federal de Minas Gerais, Programa de Pós-Graduação em História, Belo Horizonte, 2001. CORDOVIL, Daniela. On the border between culture and religion: Public policies for Afro-Brazilian religions in Brazil. Vibrant, Brasília, DF, v. 11, n. 2, p. 268-293, 2014.

CORTEN, André. Os pobres e o Espírito Santo: o Pentecostalismo no Brasil. Petrópolis: Vozes, 1996.

DEUS, Lucas Obalera de. Por uma perspectiva afrorreligiosa: estratégias de enfretamento ao racismo religioso. Rio de Janeiro: Fundação Heinrich Böll, 2019.

FLOR DO NASCIMENTO, Wanderson. O fenômeno do racismo religioso: desafios para os povos tradicionais de matrizes africanas. Revista Eixo, Brasília, DF, v. 6, n. 2, p. 51-56, 2017.

GOMES, Edlaine de Campos. Dinâmica religiosa e trajetória das políticas de patrimonialização: reflexões sobre as ações e reaçóes das religiōes afro-brasileiras. Interseçôes, Rio de Janeiro, ano 12, n. 1, p. 31-158, 2010.

KAPFERER, Bruce. In the event: Toward an anthropology of generic moments. Social Analysis, New York, v. 54, n. 3, p. 1-27, 2010.

LIDERANÇAS de matriz africana divulgam texto orientador em plenária da III Conapir. Portal Geledés, São Paulo, 10 jul. 2013. Disponível em: https:/www.geledes.org.br/liderancas-de-matriz-africana-divulgam-texto-orientador-em-plenaria-da-iii-conapir/. Acesso em: 15 maio. 2021.

MARIANO, Ricardo. Pentecostais em ação: a demonização dos cultos afro-brasileiros. In: SILVA, Vagner Gonçalves da (org.). Intolerância religiosa. 
Impactos do neopentecostalismo no campo religioso afro-brasileiro. São Paulo: Edusp, p. 119-148, 2007.

MARIZ, Cecilia Loreto. Reflexões sobre a reação afro-brasileira à Guerra Santa. Debates do NER, Porto Alegre, ano 1, n. 1, p. 96-103, nov. 1997.

MENEZES, Renata de Castro. Santos, vadias e fetos: manipulações políticas de imagens religiosas no Brasil contemporâneo. Ponto Urbe, São Paulo, n. 20, p. 1-19, 2017.

MIRANDA, Ana Paula Mendes de. Entre o público e o privado, consideraçóes sobre a (in) criminação da intolerância religiosa no Rio de Janeiro. Anuário Antropológico, Brasília, DF, n. 2, p. 125-152, 2010.

MIRANDA, Ana Paula Mendes de. A "política dos terreiros” contra o racismo religioso e as políticas "cristofascistas". Debates do NER, Porto Alegre, ano 21, n. 40, 2021.

MORAIS, Mariana Ramos de. Políticas públicas e a fé afro-brasileira: uma reflexão sobre ações de um estado laico. Ciencias Sociales y Religión/Ciências Sociais e Religiáo, Porto Alegre, v. 14, n. 16, p. 39-59, 2012.

MORAIS, Mariana Ramos de; JAYME, Juliana Gonzaga. Povos e comunidades tradicionais de matriz africana: Uma análise sobre o processo de construção de uma categoria discursiva. Civitas, Porto Alegre, v. 17, n. 2, p. 268-283, maio/ago. 2017.

MORAIS, Mariana Ramos de. De religião a cultura, de cultura a religião: travessias afro-religiosas no espaço público. Belo Horizonte: Editora PUC Minas, 2018.

NEGRÃO, Lísias Nogueira. Entre a cruz e a encruzilhada: formação do campo umbandista em São Paulo. São Paulo: Edusp, 1996.

NERY, Maria Clara Ramos. Demonização: a intolerância reavivada no campo religioso nacional. Debates do NER, Porto Alegre, ano 1, n. 1, p. 80-85, nov. 1997. 
NOGUEIRA, Sidnei. Intolerância religiosa. São Paulo: Editora Jandaíra, 2020. ORO, Ari Pedro. Neopentecostais ou afro-brasileiros: quem vencerá esta guerra? Debates do NER, Porto Alegre, ano 1, n. 1, p. 10-36, nov. 1997.

ORO, Ari Pedro. Intolerância religiosa iurdiana e reaçóes afro no Rio Grande do Sul. In: SILVA, Vagner Gonçalves da (org.). Intolerância religiosa. Impactos do neopentecostalismo no campo religioso afro-brasileiro. Sáo Paulo: Edusp, p. 29-70, 2007.

PRANDI, Reginaldo. Perto da magia, longe da política: derivaçóes do encantamento no mundo desencantado. Novos Estudos CEBRAP, São Paulo, n. 34, p. 81-91, 1992.

PRANDI, Reginaldo. Modernidade com feitiçaria: Candomblé e Umbanda no Brasil do século XX. Tempo Social, v. 2, n. 1, p. 49-74, 1990.

RUFINO, Luiz; MIRANDA, Marina Santos de. Racismo religioso: política, terrorismo e trauma colonial. Problemata: R. Intern. Fil., João Pessoa, v. 10, n. 2, p. 229-242. 2019.

SANTOS, Jocélio Teles dos. O poder da cultura e a cultura no poder. a disputa simbólica da herança cultural negra no Brasil. Salvador: Edufba, 2005.

SILVA, Vagner Gonçalves da. Prefácio ou notícias de uma guerra nada particular: os ataques neopentecostais às religiōes afro-brasileiras e aos símbolos da herança africana no Brasil. In: SILVA, Vagner Gonçalves da (org.). Intolerância religiosa. Impactos do neopentecostalismo no campo religioso afro-brasileiro. São Paulo: Edusp, p. 9-28, 2007a.

SILVA, Vagner Gonçalves da (org.). Intolerância religiosa. Impactos do neopentecostalismo no campo religioso afro-brasileiro. São Paulo: Edusp, 2007b.

SILVA JR., Hédio. Notas sobre sistema jurídico e intolerância religiosa no Brasil. In: SILVA, Vagner Gonçalves da (org.). Intolerância religiosa. Impactos do neopentecostalismo no campo religioso afro-brasileiro. Sáo Paulo: Edusp, 2007. p. 29-69. 
SOARES, Mariza de Carvalho. Guerra Santa no país do sincretismo. In: Sinais dos tempos. Diversidade religiosa no Brasil. Rio de Janeiro: ISER, p. 75-104, 1990.

SOARES, Luiz Eduardo. A guerra dos pentecostais contra o afrobrasileiro: Dimensões democráticas do conflito religioso no Brasil. Comunicaçóes do ISER, Rio de Janeiro, n. 44, p. 43-50, 1993.

Recebido em: 15/07/2021 Aprovado em: 15/07/2021 